\title{
Unusual Phenomena of the Risk-Return Relationship in Indonesia Sharia Stocks Market
}

\author{
Muhammad Anhar*, Faris Faruqi \\ Department of Management \\ Sekolah Tinggi Ilmu Ekonomi Indonesia \\ Jakarta, Indonesia \\ *muhammad_anhar@stei.ac.id
}

\begin{abstract}
This study aims to prove the existence of an unusual phenomenon in the short-term investment market of Sharia stocks in Indonesia in 2018. The usual phenomenon that is in accordance with the axiom "Risk and Return Trade-off" is "High risk - high return, low risk - low return", both for total risk, systematic risk, and specific risk. Does this phenomenon exist? An understanding of the returns and risks rankings of stock investments will be useful in the stocks analysis, especially in the analysis phase when potential investors will determine the stocks that will be the object of investment. Data on investment returns and risk of Sharia stocks are taken and processed from the IDX data. Descriptive analysis is carried out to explain the ranking of profitability, returns and risk of existing investments. Inferential analysis (Rank Difference Test) is carried out to test hypotheses about the difference between return and risk ranking. Research shows the results that rank of return and risks ratings are differ. This shows that the phenomenon of "High risk - high return, low risk - low return" does not exist in the short-term investment market of sharia stocks in Indonesia in 2018, or that the unusual phenomenon occurs.
\end{abstract}

Keywords: index, return, risk, ranking, sharia stock

\section{INTRODUCTION}

With a population that is predominantly Muslim, sharia stocks are the choice of some Indonesians to stocks investment. On the Indonesia stock exchange (market) there are currently 627 officially registered and traded stocks, 624 issuers, capitalization value of $\mathrm{Rp} 7,415,933,688,057,700$. - Of these there are $414(66.03 \%)$ sharia stocks (ISSI), $407(65,22 \%)$ issuers, with ISSI capitalization of Rp 3,861,714,080,000,000 $(52.07 \%)$, and JII capitalization of Rp 2,376,039,140,000,000 $(32.04 \%)$ [1]. The aim of investors in investing in general is to obtain the maximum return with a certain risk that is calculated, or a certain return is obtained with the minimum risk. Returns are an indicator for increasing wealth (equity) and prosperity (wealth) of investors, as well as benchmarks for growth in company stocks. Stock returns can be in the form of Capital Gain and a part of earnings (Dividends). For short-term investors, capital gain is more wanted than the dividend. Capital gains are obtained through changes in the stock market price or the stock price index of the individual companies.

Before making investment decisions, rational stock investors make an analysis of the potential returns and risks of stock investments [2]. Stock analysis consists of fundamental analysis and technical analysis. With technical analysis, investors try to forecast the potential of stock returns and risks through the values of stock technical factors (stock index and stock returns fluctuations for several periods observation).

Among sharia stocks in the stock market, potential investors still need to make a selection based on the returns and risks of their investments. Ideally, all stocks marketed have relatively the same investment return and risk, but the reality is not the case. This makes the need for investors to make a selection.

The phenomena of differences in investment returns and risk among the sharia stocks and their fluctuations raises curiosity about investor behavior in the stock market relating to these factors, especially for sharia stocks. How do investors respond to differences in investment returns and risks in making investment decisions? The respond is certainly reflected in the returns and risks that occur in the stock market. Do stocks with high investment returns carry a high investment risk? Do stocks with low investment returns carry a low investment risk?

With the background described above, this research was conducted with the aim of proving whether the phenomenon of "High Risk - High Return, Low Risk - Low Return (HR-HR, LR-LR)" occurs in the short-term investment market of sharia stocks in Indonesia or not. Therefore, the research problem is formulated in the form of a question: Does the phenomenon of "HR-HR, LR-LR" occur in the short-term investment market of sharia stocks in Indonesia? The research problem is detailed (specified) as follows:

- Do sharia stocks that obtain high return also contain high Total Risk, and vice versa?

- Do sharia stocks that obtain high return also contain high Systematic Risk, and vice versa?

- Do sharia stocks that obtain high return also contain high Specific Risk, and vice versa?

Several studies relating to stock returns and risks have been conducted, but the results vary. Martani et al. shows that profitability, turnover and market ratios have a significant impact on stock returns [3]. Research by Fama and French found that lagged profitability, asset growth, and accruals are related to average return [4]. Research by Jawadi found that by staying focused on Islamic financial products investors can expect attractive investment opportunities [5]. The Narayan 


$$
\begin{array}{cc}
\mathrm{R}_{\mathrm{i}}= & \underline{\mathrm{IHSI}} \underline{\underline{t}-\mathrm{IHSI}_{\mathrm{t}-1}} \\
\mathrm{IHSI}_{\mathrm{m}-1}= & \underline{\mathrm{IHSG}_{\mathrm{t}}-\mathrm{IHSG}_{\mathrm{t}-1}} \\
\mathrm{IHSG}_{\mathrm{t}-1}
\end{array}
$$

Whereas total risk $(\sigma)$, systematic risk $(\beta)$ and specific residual risk $\left(\sigma\left(\mathrm{e}_{\mathrm{i}}\right)\right)$ are formulated as follows [15]:

$$
\begin{aligned}
\mathrm{x} & =\frac{\sum \mathrm{xi}}{\mathrm{n}} \\
\sigma^{2} & =\frac{\sum(\mathrm{xi}-\mathrm{x})^{2}}{\mathrm{n}-1} \\
\sigma & =\sqrt{ } \sigma^{2}
\end{aligned}
$$

where $X_{\mathbf{i}}=$ period $\mathrm{i}$ stock return, $\mathrm{X}=$ average return or expected return $\{\mathrm{E}(\mathrm{r})\}$, and $\mathrm{n}=$ number of observed periods.

$$
\begin{array}{ll}
\beta= & \frac{\mathrm{n} \Sigma \mathrm{xy}-\left(\sum \mathrm{x}\right)(\Sigma \mathrm{y})}{\mathrm{n} \Sigma \mathrm{x}^{2}-(\Sigma \mathrm{x})^{2}} \\
\sigma\left(e_{i}\right)= & \sigma_{i}-\beta_{i}
\end{array}
$$

where $\mathrm{X}=$ market share returns, and $\mathrm{Y}=$ individual stock returns.

The Mann-Whitney Difference Test is used to test the hypothesis. This method is used to test the hypothesis about the difference between return rank and risk rank. The testing procedure is as follows:

Hypothesis formulation:

H10: There is no difference between ....... . rank and ........... rank of the sharia stocks.

$\mathrm{H1}_{\mathrm{a}}$ : There is a difference between ....... . rank and rank of the sharia stocks.

The level of significance $(\alpha)$ is 0,05 .

Test criteria: $\mathrm{T}$ and W Mann-Whitney

$\mathrm{T}=\sum \mathrm{R}_{\mathbf{x}}-\{\mathrm{n}(\mathrm{n}+1) / 2\}$

$\mathrm{W}_{\mathbf{1}}=(\mathrm{nm} / 2)$

$\mathrm{W}_{2}=\mathrm{Z}\{\mathrm{nm}(\mathrm{n}+\mathrm{m}+1)\} / 12$

$\mathrm{H}_{0}$ is accepted (no rank difference) if $\mathrm{W}_{1} \leq \mathrm{T}$ count $\leq \mathrm{W}_{2}$

$\mathrm{H}_{\mathbf{a}}$ is accepted (there is a difference in rank) if $\mathrm{T}$ count $<\mathrm{W}_{\mathbf{1}}$ or $\mathrm{T}$ count $>\mathrm{W}_{2}$.

The number of stocks $=30$, means that $\mathrm{n}_{1}=30$ and $\mathrm{n}_{2}=30$

\section{RESULTS AND DISCUSSION}

From the descriptive statistical analysis, the following research results were obtained:

- Sharia stock returns have a minimum value of -4.73 achieved by PT. Pembangunan Perumahan, a maximum value of 20.30 achieved by PT. Surya Citra Media, the median value of -0.18 achieved by PT. Wijaya Beton Precast, and average return 0.62. The average return of
Individual stock returns $\left(\mathrm{R}_{\mathbf{i}}\right)$ and market stock returns $\left(R_{\mathbf{m}}\right)$ are formulated as follows [14]: 
Islamic stocks carry the risk of obtaining a negative return (loss of capital) $14.39 \%(=062 \%-15.01 \%)$.

average return of $0.62 \%$ per month.

- The total investment risk of sharia stocks has a minimum value of 3.82 faced by PT. Telkom Indonesia, the maximum value of 99.41 faced by PT. Surya Citra Media, the median value of 11.97 faced by the stocks of PT. XL Axiata, and the average is 15.01. The average total risk of 15.01 means that sharia stocks in 2018 face the risk of obtaining a reward of $15.01 \%$ lower than the expected reward.

- Systematic risk of sharia stock investment has a minimum value of -1.32 faced by PT. Pembangunan Perumahan, a maximum value of 4.93 faced by PT. Wijaya Karya, the median value of 1.40 faced by PT. AKR Corporindo, and the average of 1.54. A systematic risk rate of 1.54 means that sharia stocks in 2018 face the risk to decrease return of $1.54 \%$ when market returns decrease by $1 \%$.

The specific / residual risk of sharia stocks has a minimum value of 3.40 faced by PT. Telkom Indonesia, the maximum value of 99.98 faced by PT. Surya Citra Media, the median value of 11.06 faced by PT. Indocement Tunggal Perkasa, and average 13.48. The average residual risk of 13.48 means that sharia stocks in 2018 face the risk to decrease return of $13.48 \%$ when the company's financial performance falls.

TABLE I. FROM THE HYPOTHESIS TEST THE FOLLOWING RESEARCH RESULTS ARE OBTAINED

\begin{tabular}{|c|l|l|l|l|l|}
\hline $\mathbf{H}$ & \multicolumn{1}{|c|}{ Hypothesis } & T Count & & $\mathbf{W}$ & Conclusion \\
\hline $\mathrm{H} 1_{\mathbf{a}}$ & $\begin{array}{l}\text { Return rank is different } \\
\text { from the total risk rank }\end{array}$ & 0 & $<$ & 450 & $\begin{array}{l}\text { Ha received } \\
\text { (different } \\
\text { rank) }\end{array}$ \\
\hline $\mathrm{H} 2_{\mathbf{a}}$ & $\begin{array}{l}\text { Return rank is different } \\
\text { from systematic risk rank }\end{array}$ & 0 & $<$ & 450 & $\begin{array}{l}\text { Ha received } \\
\text { (different } \\
\text { rank) }\end{array}$ \\
\hline $\mathrm{H} 3_{\mathbf{a}}$ & $\begin{array}{l}\text { Return rank is different } \\
\text { from residual risk rank }\end{array}$ & 0 & $<$ & 450 & $\begin{array}{l}\text { Ha received } \\
\text { (different } \\
\text { rank) }\end{array}$ \\
\hline
\end{tabular}

\section{A. Sharia Stock Return Rank is Differ than the Total Risk} Rank

The results of this study prove that there is a significant difference between the rank of sharia stock returns with their total risk rank. This means that stocks that get high returns do not always face a higher total risk than stocks that get low returns, and stocks that get low returns do not always face lower total risk than stocks that get high returns. In other words, stocks that earn high return may face low total risk. Likewise, on the other hand, a stock that receives a low return may face a high total risk. So it can be said that the phenomenon of "high risk - high return, low risk - low return" does not occur in the sharia stock market in Indonesia. This is an unusual phenomenon, contrary to the axiom / general rule "Risk and Return Trade-off".

The total risk itself shows the potential for obtaining a return not in accordance with the expected return. An average return of $0.62 \%$ with a systematic risk of $15.01 \%$ means that

\section{B. Sharia Stock Return Rank is Differ than the Systematic Risk Rank}

The results of this study prove that there is a significant difference between the rank of sharia stock returns with its systematic risk rank. This means that stocks that get high returns do not always face higher systematic risk than stocks that get low returns, and stocks that get low returns do not always face lower systematic risk compared to stocks that get high returns. In other words, stocks that earn high returns may face low systematic risk. Likewise, on the other hand, a stock that receives a low return may face a high systematic risk. So it can be said that the phenomenon of "high risk -high return, low risk - low return" does not occur in the sharia stock market in Indonesia. This is an unusual phenomenon, contrary to the axiom / general rule "Risk and Return Trade-off".

Systematic risk itself shows the potential decline in rewards obtained when market stock returns (stocks in general) fall. Systematic risk of an average of $1.54 \%$ means that in Islamic stocks there is a potential for a $1.54 \%$ reduction in return when market stocks generally only fall by $1 \%$.

\section{Sharia Stock Return Rank is Different from the Residual Risk Rank}

The results of this study prove that there is a significant difference between the rank of Islamic stock returns with the rank of residual risk. This means that stocks that get high returns do not always face a higher residual risk than stocks that get low returns, and stocks that get low returns do not always face lower residual risk than stocks that get high returns. In other words, stocks that earn high rewards may face low residual risk. Likewise, on the other hand, stocks that receive low returns may face high residual risk. So it can be said that the phenomenon of "high risk-high return, low risklow return" does not occur in the Islamic stock market in Indonesia. This is an unusual phenomenon, contrary to the axiom/general rule "Risk and Return Trade-off".

The residual risk itself is mathematically a residual risk, i.e. the remaining risk after the total risk is reduced by systematic risk. Residual risk is often identified with specific risk, that is risk that shows the potential for obtaining return that are not in accordance with the expected return when the company's financial performance decreases. The company's financial performance can be measured by its financial ratios. Because residual risk is identified with specific risk, the average residual risk of $13.48 \%$ means that in sharia stocks there is generally a potential decrease in return of $13.48 \%$ when the company's financial performance decreases.

The implication of this unusual phenomenon is that a prospective stock investor must not make a trade-off between stock returns and stock risk. Prospective investors can choose stocks that have high potential returns with the low potential risk at the same time. 
[5] F. Jawadi, N. Jawadi, and W. Louhichi, "Conventional and Islamic stock price performance: An empirical investigation," International Economics, vol. 137, pp. 73-87, 2014.

Research shows the results that rank of return and risks ratings are differ. This shows that the phenomenon of "High risk - high return, low risk - low return" does not exist in the short-term investment market of sharia stocks in Indonesia in 2018 , or that the unusual phenomenon occurs.

\section{ACKNOWLEDGMENT}

Thanks to the Indonesian Stock Exchange for providing stock data and other relevant data for free. Thanks also to the Indonesian College of Economics (Sekolah Tinggi Ilmu Ekonomi Indonesia) in Jakarta for providing supporting facilities so that this research was carried out well.

\section{REFERENCES}

[1] IDX, [Online] Retrieved from: http://www.idx.co.id, January 2019.

[2] S.K. David and I. Kurniawan, Manajemen Investasi - Pendekatan Teknikal dan Fundamental Untuk Analisis Saham. Yogyakarta: Graha Ilmu, 2016.

[3] D. Martani, Mulyono, and R. Khairurizka, "The effect of financial ratios, firm size, and cash flow from operating activities in the interim report to the stock return," Chinese Business Review, vol. 8, no.(6), pp. 44-55, 2009.

[4] E.F. Fama and K.R. French, "Profitability, investment and average returns," Journal of Financial Economics, vol. 82, no. 3, pp. 491-518, 2006.
[6] P.K. Narayan and D. Bannigidadmath, "Does Financial News Predict Stock Returns? New Evidence from Islamic and Non-Islamic Stocks," Pacific-Basin Finance Journal, vol. 42, pp. 1-22, 2015.

[7] M. Anhar, "The Rating of Sectoral Stocks Based on Their Capital Gain, Advances in Economics, Business and Management Research," Proceedings of the 5th Annual International Conferences on Management Research, Atlantis Press, vol. 74, 2018.

[8] Endri, "Analisis Teknikal dan Fundamental Saham : Aplikasi Model Data Panel,” Jurnal Akuntabilitas, vol.8, no. 1, pp 90-96, 2008.

[9] Sudarto, Khrisnoe and Tohir, "Analisis Return Saham dan Faktor-faktor yang Mempengaruhinya,” JERA, vol. 1, no. 1, pp. 43-51, 1999.

[10] S. Natarsyah, Analisis Pengaruh Beberapa Faktor Fundamental dan Risiko Sistematik Terhadap Harga Saham - Bunga Rampai Kajian Teori Keuangan. Yogyakarta: BPFE, 2012.

[11] L.C. Bhandari, "D/E Ratio and Expected CS Return: Empirical Evidence," Journal of Finance, vol. 43, June 1998.

[12] Zulbahnidar and Jontus, "Pengaruh Risiko dan Leverage Keuangan Riau-Pekanbaru Terhadap Tingkat Keuntungan Dalam Sektor Properti dan Real Estat di BEJ,” Jurnal Penelitian Riset Akuntansi IX, FE, 2002.

[13] P.M. Healy and K.G. Palepu, "Earnings and Risk Changes Surrounding Primary Stock Offers," Journal of Accounting Research, vol. 28 no. 1, 1990.

[14] Jogiyanto, Teori Portofolio dan Analisis Investasi, 3rd ed. Yogyakarta: BPFE, 2016.

[15] R.I. Levin and D.S. Rubin, Statistics for Management, 7th ed. New Jersey: Prentice-Hall International Inc, 2015. 